The Knowledge Retrieval Matrix:

Codification and Personification as Separate Strategies

Jens Gammelgaard \& Thomas Ritter

CKG WP 10/2004 
CKG Working Paper No. 10/2004

ISBN: 87-91506-25-5

Department of Management, Politics and Philosophy

Copenhagen Business School

The Center for Knowledge Governance

Blaagaardsgade $23 \mathrm{~B}$

DK-2200 Copenhagen N

Denmark

Phone +4538153630

Fax $\quad+4538153635$

E-mail: ckg.Ipf@cbs.dk

www.cbs.dk/ckg 


\title{
The Knowledge Retrieval Matrix: Codification and Personification as Separate Strategies
}

\author{
Jens Gammelgaard \\ Thomas Ritter \\ Copenhagen Business School \\ Department of International Economics and Management
}

Howitzvej 60,1

2000 Frederiksberg

Denmark

CKG WP 10/04 


\title{
The Knowledge Retrieval Matrix: Codification and Personification as Separate Strategies
}

\begin{abstract}
Previous discussions of knowledge transfer within multinational corporations tended to focus on the process as an isolated phenomenon and on the factors that impede the process. Less attention has been given to how the individual knowledge worker retrieves or identifies, and then decodes knowledge accessed from the corporate memory. We suggest that multinational companies (MNCs) solve knowledge retrieval problems by implementing virtual communities of practice - intranet-based collaborative forums. Codification and personalization strategies have previously been emphasized as an either-or solution. These virtual communities of practice combine the codification and personalization strategies, simultaneously utilizing the advantages of two approaches.
\end{abstract}




\section{Introduction}

Knowledge and its management have moved up the corporate agenda due to the idea that knowledge is a source of competitive advantage. Knowledge management strategies are used to identify where best practices and experts are located in the organization (Davenport \& Prusak, 1998). Today, knowledge-intensive corporations in particular view their employees as knowledge workers (May et al., 2002). A knowledge worker depends on an internal supply of recent corporate knowledge, but is also feeding knowledge into the organization.

The transfer of knowledge is, however, not an easy process. Barriers to knowledge transfer can be roughly categorized into three categories: fragmentation, overload and decontextualization. Firstly, knowledge is dispersed throughout the organization and thus "unknown" to the individual employee. Therefore, knowledge is often inaccessible to relevant knowledge workers, which causes inefficiencies. Teece (2001, p. 128) notes: 'Knowledge, which is trapped inside the minds of key employees, in filing drawers and databases, is of little value if it is not supplied to the right people at the right time'. This aspect is particularly true for MNCs, which are often geographically dispersed and localized in various sub-units (Hedlund, 1999): Thus, knowledge acquired at one site can be beneficial to other sites (Buckley \& Carter, 2002; Olivera, 2000). In order to overcome the fragmentation problem, firms have intensified their efforts to make knowledge available across the organization. Strategies like "total openness in internal communication", where everyone has full access to the organization's information and is aware of the others' repertoire (Grant, 1996), allow a tremendous amount of information to be available to the individual.

However, while solving the fragmentation problem, these efforts have produced an information overload problem. To give one example, the consultancy company Ernst and Young estimates that it has 1.2 million documents in its general unfiltered repository, 875,000 documents in its discussion databases, and 50,000 documents in comprehensive packs of material on specific topics (Wenger et al., 2002). In practice, this situation is impossible for the individual knowledge worker to handle, simply due to the information overflow. One can say that the knowledge is now hidden by knowledge or, as in the famous saying: "They cannot see the forest because of the trees”. Overloaded knowledge platforms lead to a low usage rate and have also been characterized by McDermott (1999) as "information junkyards". 
The third problem, de-contextualization, relates to all those situations where knowledge was located but could not be retrieved due to problems understanding the matter. The gap between the sender and the receiver of the information may be due to cultural, technical, and organizational distance.

Overcoming the above three problems and developing efficient knowledge identification and transfer processes are key elements of knowledge management practices leading to new ways of exploiting existing valuable knowledge (Cohendet et al., 1999; Dunford, 2001). Ideally, the individual knowledge worker must be able to retrieve the stored knowledge in order to, for example, service the customer without re-inventing the wheel.

The retrieval processes take place in an interface between social interaction and technology. This division reflects the fact that organizations typically operate with two different knowledge management strategies, a codification strategy, where knowledge is codified and stored in databases, and a personalization strategy, where personal interaction is essential and information technology is only a tool for communication between people (Hansen et al., 1999).

This paper addresses the fragmentation, overload and retrieval problems by discussing the development of virtual communities of practice as a potential solution. The argumentation focuses on the combined use of weak and strong tie-binding practices through the establishment of virtual communities of practice. Previous research often viewed personalization and codification strategies solely as instruments, with opposing points on the scale, seldom taking the perspective of their interdependency. The paper offers an alternative a combination of the two strategies.

\section{The Knowledge Retrieval Process}

There are many highly diverse understandings of knowledge. Davenport \& Prusak (1998, p. 5) define knowledge as 'a fluid mix of framed experience, values, contextual information, and expert insight that provides a framework for evaluating and incorporating new experiences and information. It originates and is applied in the minds of knowledge senders. In organizations, it often becomes embedded not only in documents of repositories but also in organizational routines, processes, practices, and norms.' Knowledge is seen as a mixture of various elements, which are sometimes codified and sometimes tacit. In this paper, 
knowledge is interpreted as pieces of information serving a specific need. The focus here is how the individual is able to retrieve knowledge from the organizational memory.

Krippendorff (1975, p. 19) defines retrieval as 'processes by which information is reconstituted or reconstructed and made available,' using the example of 'reading documents for what is encoded in them.' The emphasis lies on how individuals will be able to - correctly - understand knowledge retrieved from organizational memory. For example, how is knowledge obtained from a written document from a corporate database understood? According to Krippendorff (1975), retrieval consists of search and decoding processes. Search is the process by which retained information is selected as relevant to a particular problem or goal. Decoding is the reconstruction of the selected information to satisfy the user's request. It is, therefore, useful to divide the retrieval process into two steps: the identification of knowledge, and the receivers' individual decodification of the accessed knowledge. Information technology makes it possible for an individual to identify and select a specific piece of schematized information. However, decoding, in the sense of creating meaning, is problematic. Context specificity and lack of absorptive capacity in general cause a problem (Cohen \& Levinthal, 1990; Szulanski, 2000). A sender of knowledge (such as the person writing the document and subsequently storing it in a database) will typically design text so it gives meaning in his own context. The receiver will likewise decode knowledge with respect to his own context in order to apply information in a specific situation (Shotter, 1993; Wenger, 1998). A contextual gap exists - in such forms as age, sex, social position, religion, and political conviction - between the sender and the receiver, which keeps them apart (Nahapiet and Ghoshal, 1998). Shared context and frequent communication between the sender and the receiver minimizes this distance (Reddy, 1979; Deetz, 1992). If a shared context and frequent communication is not possible (like in MNCs), the knowledge receiver often needs the original informant to decode a particular piece of information. However, the informant may be unknown to the retriever (Alavi \& Leidner, 2001) and may have even left the firm.

An important consideration when storing knowledge is, therefore, to include contextual background information. When the context surrounding the knowledge creation process is not shared, it is questionable whether retrieval will result in effective use (Alavi \& Leidner, 2001). An individual decoding knowledge, therefore, needs some kind of "codebook" to understand the written document, a codebook that is often not manifest in communities of 
individuals who share a context. To the outside observer, this group appears to be using a large amount of tacit knowledge (Cowan et al., 2000). This indicates more effective retrieval processes within communities.

\section{Four knowledge retrieval means}

Two approaches are discussed in the literature in relation to knowledge transfer: personalization and codification strategies. These two approaches have also been related to the use of weak and strong ties between individuals (Hansen, 1999; Rindfleisch \& Moorman, 2001).

Weak ties cover distant, infrequent relationships between individuals, whereas strong ties refer to close, frequent, long lasting, personalized relationships, which in turn reflect the personalization approach. Weak ties between units are helpful to searching or scanning for information, whereas strong ties are needed to transfer complex knowledge (Granovetter, 1972; Hansen, 1999; Steensma \& Carley, 2000). Complex knowledge is hard to encode and decode through communication technologies (Huber, 1991), so individuals first and foremost retrieve "additional and peripheral” knowledge though electronic modes. Complex knowledge is likely to be transferred through socialization processes in which knowledge is transferred in tacit form from one actor to another (Cohendet et al., 1999; Nonaka and Takeuchi, 1995). To give one example, Lagerström and Andersson (2003) find socializing strategies to be key to knowledge sharing among transnational team members, whereas the use of information technologies is seen as secondary in this respect.

Often the codification and personalization approaches are treated as opposite ends of one scale. In this paper, the two strategies are dealt with as different, yet complementary, dimensions of knowledge retrieval. The coexistence of these strategies leads to the following model.

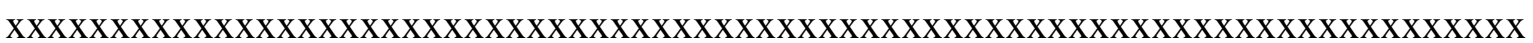

Figure 1 to be inserted here

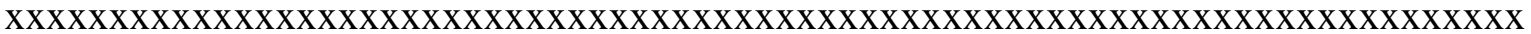

\section{Individual Memory}

Individual memory is developed through a person's observations, experiences, and actions (Alavi \& Leidner, 1999) and consists of semantic, episodic and skill-based memory. Semantic 
knowledge refers to general knowledge stored in a network of concepts, whereas episodic knowledge applies to individual experiences, and skill knowledge encompasses implicit knowledge of how to do things (Stein \& Zwass, 1995; Tulving, 1983). Knowledge of this type makes sense to the individual and is codified at this level, rather than at the organizational level. This knowledge is not part of the organizational memory, since it is not stored and can only be brought to bear on present activities, resulting in organizational behaviour changes (Walsh \& Ungson, 1991; Stein \& Zwass, 1995). The simultaneously low degrees of organizational codification and personalization strategies reveal isolated retrieval processes drawing on individual memory alone. An example is those experts who solely retrieve information from their personal memory, and make use of neither personal networks nor databases.

\section{Databases}

Taking the large amount of fragmented information in MNCs into consideration, the use of information technology in this respect is viewed as central to the internalisation of the MNCs knowledge (Wright \& Edwards, 2001). These knowledge platforms provide a repository of codified knowledge (Constant et al. 1997; Pickering and King, 1995; Purvis et al., 2001) and, in the long run, the technology reduces the individual effort needed to retrieve information, effort of individuals who are often separated in time and physical proximity (Huber, 1991). In fact, through the use of databases, more people, or at least their written documents, serve as sources of information to the individual knowledge worker. The establishment of a link between local and function-based knowledge, and making this knowledge computerized and globally accessible are seen as key success factors (D’Adderio, 2001). By 'globalising' knowledge, all members of an organization are, in theory, able to retrieve similar information from the organizational memory. Through these 'thought collectives' (Halbwachs, 1992), individuals prompt each other to recollect information and remember the past more efficiently.

The risk of data overflow has emphasized the need to reduce data into recognizable patterns of information through the use of computer algorithms (Norton, 2000). Databases have also been used to systemize information offered to the knowledge worker and have been developed to effectively guide the users in their selection processes. A database provides access to different knowledge sources like the corporate intranet, the Internet, and more 
specialized search software. Among search possibilities are: a) best practices and codified procedures, b) corporate goals, like ethical statements, and c) customer and competitor intelligence, such as market reports. This blueprint idea systemizes and, in fact, trivializes the knowledge needed for serving clients. In a way, this combination of codification deskills the knowledge worker, who does not need to possess certain qualifications to carry out a task (Alvesson \& Kärreman, 2001)

\section{Social Capital}

This study employs an "egocentric" perspective on social capital (Lesser 2000). The term social capital refers to 'the value of an individual's relationships with other individuals in helping to get things done in a firm' (McElroy, 2002, p. 31) or, in other words, 'the sum of actual and potential resources embedded within, available through, and derived from the network of relationships possessed by an individual or a social unit' (Nahapiet and Ghoshal, 1998). Addressing a knowledge management perspective, Daniel et al. (2003, p. 116) define social capital as: ' a common social resource that facilitates information exchange, knowledge sharing and knowledge construction through continuous interaction, built on trust and maintained through shared understanding.' The different authors also state that there must be series of connections that individuals have to others. In other words, individuals must perceive themselves to be part of the network. In addition, a sense of trust must be developed across connections.

The concept of social capital is attributed to Coleman (1988), who refers to Granovetter's (1985) importance of the social structure. Social capital was originally addressed in sociology, political science, and economic development literature (e.g. Coleman, 1988, Putnam, 1995, Woolcock, 1998, Portes, 1998) and has recently been applied to business and management issues (e.g. Burt, 1997, Walker et al., 1997, Cohen and Fields, 1998).

Social capital is included in this study to represent the personification strategy. In essence, personification strategies in MNCs aim at building stronger connections between members of a unit, hereby increasing their social capital. Social capital can also be defined on both the individual and unit/organizational levels. This allows use of the concept for a given knowledge worker and for a group of knowledge workers dealing with a customer request. In addition, the notion of trust is important because only qualified sources will be accounted for in the knowledge transfer process. Social capital bridges cultural differences (Daniel et al. 
2003), and is - per definition - based on trust-based relationships (Jarvenpaa and Leidner, 1999). The advantage of high social capital is the common understanding that allows efficient retrieval because the sender and receiver share a common code (Cowan et al., 2001, Lave and Wenger, 1991; Brown and Duguid, 1991).

\section{Virtual Communities of Practice}

According to Wenger et al. (2002, p.4): 'Communities of practice are groups of people who share a concern, a set of problems, or a passion about a topic, and who deepen their knowledge and expertise in this area by interacting on an ongoing basis'. It is often the passion for something that brings people together, since an individual naturally seeks to share insights and build knowledge in areas of interest to them (McDermott, 1999). This differs from informal networks of people who communicate, share information and build relationships, since the community of practice is about something specific. The group intends to build practices and develop domains of knowledge with a unique perspective. Given this uniqueness, newcomers to the community need to learn how to function in the entity (Lave \& Wenger, 1991; Nonaka et al., 2001). Communities of practice have often been assessed as efficient in transferring tacit and complex knowledge among their participants (Brown and Duguid, 1991; Gertler, 2003).

Virtual communities are similar to communities of practice - a group of frequently interacting individuals sharing a practice. The difference is that communication and coordination of work takes place in cyberspace through information technology. The community is, therefore, relational without reference to a specific location (Ahuja and Carley, 1999). Koh and Kim (2004) speak of a distributed community of practices, and refer to a group of geographically distributed individuals who are informally bound together by shared expertise and shared work interests. Like communities of practice, they operate with informal goals, a common language, shared understandings and reasonable levels of trust. Through the establishment of virtual communities of practice, the codification and personalization strategies can be combined. Sometimes, virtually connected teams build a relationship through face-to-face meetings before they effectively collaborate electronically (McDermott, 1999)

A MNC is a constitution of different communities of practice and these communities are interdependent groups rather than isolated entities (Brown \& Duguid, 1991; Gherardi \& 
Nicolini, 2002). The boundary of each community is defined by its task, culture and history (Nonaka et al., 2001), and its participants are well defined rather than randomly selected (Kuhn, 1962). This might lead to encapsulated structures facing Not-Invented-Here problems (Katz \& Allen, 1982), since specialists intend to further specialize rather than move into new areas (Kuhn, 1962). Knowledge, therefore, flows more easily within the communities than among them (Kogut \& Zander, 1995; Teece, 2001). As Kuhn (1962, p.177) states, communication within a community is: 'relatively full and professional judgment relatively unanimous... professional communication across group lines is sometimes arduous, often results in misunderstanding, and may, if pursued, evoke significant and previously unsuspected disagreements.'

However, information travels fast within communities and is readily accessible by other members (Brown \& Duguid, 1991). Establishment of a community focused on a topic narrows identification processes, since the group of participants will include the group of experts, regardless of where they are physically located in the organization. Furthermore, the ongoing decoding practices will be improved over time, since stable communication practices are foreseeable and the knowledge worker knows persons in the organization who can be helpful with providing contextual background information (Brown and Duguid, 2001; Wenger, 1998). The question is whether these fluent knowledge transfers are evident in a virtual context. As Wenger (1998, p.74) writes: 'Given the right context, talking on the phone, exchanging electronic mail, or being connected by radio can all be part of what makes mutual engagement possible.' On the one hand, geographical distance obviously creates problems for the distributed communities: people do not meet by chance, face-to-face contact is rare, no informal network relationship building takes place, participants are from different cultural backgrounds and represent organizational units possessing different powers, and finally trust building is unlikely (Wenger et al., 2002). On the other hand, distributed communities exist among scientists spread across the globe who are still able to create new knowledge. In fact, Kuhn (1962) states that the creation of new scientific paradigms is based on the foundation of geographical dispersed scientific communities.

A recent example of a well-functioning virtual community is the development of the Linux operating system. In the development of this system, thousands of volunteers, dispersed among both organizational and geographical groups, collaborated via the Internet (Lee and Cole, 2003). Walther (1995) suggests that it is possible to build close on-line social 
relationships, but in general they are more difficult and time-consuming to achieve. Gertler (2003) believes that even tacit knowledge will flow across regional and national boundaries if the virtual community is 'strong enough'. In general, the combination of narratives or storytelling techniques with the use of boundary objects as documents makes the virtual community of practice useful for retrieval processes (Boland and Tenkasi, 1995). In terms of searching, decoding and subsequent application of stored information, virtual communities of practice are expedient: they offer direct, simultaneous access to the written document and its author, together with related database entries.

The use of electronic communication technology can raise the frequency of contacts among individuals and, in general, increases the opportunity for dialogue among organizational parts of an MNC that otherwise would not be in contact. By establishing linkages between units and individuals and by standardizing information flows (Bowman, 2002; Ensign, 1998), information technology becomes a preferable and cost efficient instrument for building knowledge platforms, which are both codified and personal. MNCs have tried to implement such virtual communities of practice with special sections on their intranet, sections that are reserved for community members, or through increased localization of competences through the publication of colleagues' curriculum vitae on the intranet.

\section{Conclusion}

In this paper, we have promoted the idea that codification and personification are not opposing ends of a "knowledge transfer scale". Rather, we have argued that these two strategies are two dimensions that can be combined. This has lead to the development of a matrix with four different knowledge retrieval situations, which are discussed here. With this matrix, some topical concepts, such as knowledge databases, social capital, and virtual communities of practice, were placed in relation to each other. Thus, the matrix allows for a holistic view of the knowledge retrieval issue.

We suggest virtual communities of practice are an opportunity for internationally-operating corporations that cannot develop regular face-to-face contact between employees but still need some degree of personification for efficient knowledge transfer. Virtual communities can help the knowledge worker to restore context where it is missing from information, and also help to create shortcuts through the massive amount of data offered through the corporate intranet. By joining a virtual community of practice, the knowledge-worker takes advantage 
of the simultaneous use of several boundary objects together with conversations with knowledge senders via such media as e-mail, phone, and videoconferences.

We suggest that businesses (or virtual communities within MNCs) copy the structure from scientific communities where members occasionally meet at conferences or pay each respective organization a short visit. They then subsequently cooperate in such aspects as the retrieval of information from shared written documents in a virtual context.

We further recommend that firms analyze their existing knowledge transfer practise in order to determine potential for improvement. Our empirical work has shown us that firms tend to overstress one strategy and neglect the other. Notions of “either-or" decisions normally justify this. However, our approach of separating the two strategies allows a company to implement both at the same time. The matrix may also guide the development of “ideal” situations, such as those in which retrieval mechanisms should be applied for different projects, units or issues. 


\section{References}

Ahuja, M. K. and Carley, K. M. (1999), "Network structure in virtual organizations", Organization Science, Vol 10 No 6, pp. 741-757.

Alavi, M. and Leidner, D. (2001), "Review: knowledge management and knowledge management systems: conceptual foundations and research issues”, MIS Quarterly, Vol 25 No 1, pp. 107-136.

Alvesson, M. and Kärreman, D. (2001), "Odd couple: making sense of the curious concept of knowledge management”, Journal of Management Studies, Vol 38 No 7, pp. 995-1018.

Boland, R. J. and Tenkasi, R. V. (1995), "Perspective making and perspective taking in communities of knowing”, Organization Science, Vol 6 No 4, pp. 350-372.

Bowman, B. J. (2002), "Building Knowledge Management Systems”, Information Systems Management, Vol 19 No 3, pp. 32-40.

Brown, J. S. and Duguid, P. (1991), "Organizational learning and communities-of-practice: toward a unified view of working, learning and innovation”, Organization Science, Vol 2 No 1, pp. 40-57.

Brown, J. S. and Duguid, P. (2001), "Knowledge and organization: a social-practice perspective”, Organization Science, Vol 12 No 2, 198-213.

Buckley, P. J. and Carter, M. J. (2002), "Process and structure in knowledge management practices of British and US multinational enterprises", Journal of International Management, Vol 8 No 1, pp. 29-48.

Burt, R. S. (1997), “The contingent value of social capital”, Administrative Science Quarterly, Vol 42 No 2, pp. 339-365.

Cohen, W. M. and Levinthal, D. A. (1990), "Absorptive capacity: a new perspective on learning and innovation”, Administrative Science Quarterly, Vol 35 No 1, pp. 128-152.

Cohendet, P, Kern, F., Mehmanpazir, B. and Munier, F. (1999), "Knowledge coordination, competence creation and integrated networks in globalised firms", Cambridge Journal of Economics, Vol 23 No 2, pp. 225-241.

Coleman, J. S. (1988), “Social capital in the creation of human capital”, American Journal of Sociology, Vol 94, pp. S95-S120.

Constant, D., Sproull, L. and Kiesler, S. (1997), "The kindness of strangers: on the usefulness of electronic weak ties for technical advice”, In Kiesler, S. (Ed.) Culture of the Internet, Lawrence Erlbaum Associates, Mahwah, NJ, pp. 303-322.

Cowan, R., David, P. A. and Foray, D. (2000), "The explicit economics of knowledge codification and tacitness”, Industrial and Corporate Change, Vol 9 No 2, pp. 211-253.

D'Adderio, L. (2001), "Crafting the virtual prototype: how firms integrate knowledge and capabilities across organizational boundaries”, Research Policy, Vol 30 No 9, pp. 14091424.

Daniel, B., Schwier, R. A. and McCalla, G. (2003), "Social capital in virtual learning communities and distributed communities of practice", Canadian Journal of Learning and Technology, Vol 29 No 3, pp. 113-139.

Davenport, T. and Prusak, L. (1998), Working knowledge, how organizations manage what they know, Harvard Business School Press: Boston, Mass.

Deetz, S. A. (1992), Democracy in an age of corporate colonization: developments in communication and the policies of everyday life, Albany: State University of New York Press: New York. 
Dunford, R, (2000), "Key challenges in the search for the effective management of knowledge in management consulting firms", Journal of Knowledge Management, Vol 4 No 4, pp. 295-302.

Ensign, P. C. (1998), "Interrelationships and horizontal strategy to achieve synergy and competitive advantage in the diversified firm”, Management Decision, Vol 36 No 10, pp. 657-668.

Gertler, M. S. (2003), "Tacit knowledge and the economic geography of context or the undefinable tacitness of being (there)”, Journal of Economic Geography, Vol 3 No 1, pp. 75-99.

Gherardi, S. and Nicolini, D. (2002), "Learning in a constellation of interconnected practices: canin or dissonance?”, Journal of Management Studies, Vol 39 No 4, pp. 419-436.

Granovetter, M. S. (1972), “The strength of weak ties”, American Journal of Sociology, Vol 78 No 6, pp. 1360-1380.

Granovetter, M. S. (1985), "Economic action and social structure: the problem of embeddedness", American Journal of Sociology, Vol 91 No 3, pp. 481-510.

Grant, R. M. (1996), “Toward a knowledge-based theory of the firm”, Strategic Management Journal, Vol 17 No Winter Special Issue, pp. 109-122.

Hansen, M. T. (1999), "The search-transfer problem: the role of weak ties in sharing knowledge across organization subunits”, Administrative Science Quarterly, Vol 44 No 1, pp. 82-111.

Hansen, M. T., Nohria, N. and Tierney, T. (1999), "What's your strategy for managing knowledge?”, Harvard Business Review, Vol 77 No 2, pp. 106-116.

Halbwachs, M. (1992), On Collective Memory, University of Chicago Press, Chicago.

Hedlund, G. (1999), "The intensity and extensity of knowledge and the multinational corporation as a nearly recomposable system (NRS)”, Management International Review, Vol 39 No 1, pp. 5-44.

Huber, G. P. (1991), “Organizational learning: the contributing process and the literatures”, Organization Science, Vol 2, No 1, pp. 88-115.

Jarvenpaa, S. L. and Leidner, D. E. (1999), "Communication and trust in global virtual teams”, Organization Science, Vol 10 No 6, pp. 791-815.

Katz, R. and Allen, T. J. (1982), "Investigating the Not Invented Here (NIH) syndrome: a look at the performance, tenure, and communication patterns of $50 \mathrm{R} \& \mathrm{D}$ project groups", $R$ \& D Management, Vol 12 No 1, pp. 7-19.

Kogut, B. and Zander, U. (1995), "Knowledge and the speed of the transfer and imitation of organizational capabilities: an empirical test”, Organization Science, Vol 6 No 1, pp. 76-91.

Koh, J. and Kim, Y. G. (2004), "Knowledge sharing in virtual communities: an e-business perspective”, Expert Systems with Applications, Vol 26 No 2, pp. 155-166.

Krippendorff, K. (1975), "Some principles of information storage and retrieval in society", General Systems, Vol 20, pp. 15-35.

Kuhn, T. S. (1962), The structure of scientific revolutions, The University of Chicago Press, Chicago.

Lagerström, K. and Andersson, M. (2003), "Creating and sharing knowledge within a transnational team - the development of a global business system", Journal of World Business, Vol 38 No 2, pp. 84-95.

Lave, J. and Wenger, E. (1991), Situated learning: legitimate peripheral participation, Cambridge University Press, Cambridge. 
Lee, G. K. and Cole, R. E. (2003), "From a firm-based to a community-based model of knowledge creation: the case of the Linux kernel development", Organization Science, Vol 14 No 6, pp. 633-649.

Lesser, E. (2000), Knowledge and social capital, Butterworth Heinemann: Boston.

May, T. Y., Korczynski, M. and Frenkel, S. J. (2002), "Organizational and occupational commitment: knowledge workers in large corporations”, Journal of Management Studies, Vol 39 No 6, pp. 775-801.

McElroy, M. (2002), "Social innovation capital”, Journal of Intellectual Capital, Vol 3 No 1, pp. 30-39.

McDermott, R. (1999), "Why information technology inspired but cannot deliver knowledge management”, California Management Review, Vol 41 No 4, pp. 103-117.

Nahapiet, J. and Ghoshal, S. (1998), "Social capital, intellectual capital, and the organizational advantage”, Academy of Management Review, Vol 23 No 2, pp. 242-266.

Nonaka, I. and Takeuchi, H. (1995), The knowledge-creating company - how Japanese companies create the dynamic of innovation, Oxford University Press, Oxford.

Nonaka, I., Toyama, R. and Konno, N. (2001), "SECI, Ba and leadership: a unified model of dynamic knowledge creation”, In Nonaka, I. and Teece, D.J. (Eds.), Managing Industrial Knowledge: Creation, Transfer and Utilization, Sage Publications, London, pp. 13-43.

Norton, M. (2000), "Knowledge discovery with a little perspective", American Society for Information Science: Bulletin of the American Society for Information, Vol 27 No 1, pp. 2123.

Olivera, F. (2000), "Memory systems in organizations: an empirical investigation of mechanisms for knowledge collection, storage and access", Journal of Management Studies, Vol 37 No 6, pp. 811-832.

Pickering, J. M. and King, J. L. (1995), "Hardwiring weak ties: interorganizational computermediated communication, occupational communities, and organizational change", Organization Science, Vol 6 No 4, pp. 479-486.

Portes, A. (1998), "Social capital: its origins and applications in modern sociology", Annual Review of Sociology, Vol 24, pp. 1-24.

Purvis, R. L., Sambamurthy, V. and Zmud, R. W. (2001), “The assimilation of knowledge platforms in organizations: an empirical investigation, Organization Science, Vol 12 No 2, pp. 117-135.

Putnam, R. 1995, "Bowling alone: America's declining social capital”, Journal of Democracy, Vol 6, pp. 65-78.

Reddy, M.L. (1979), “The conduit metaphor: a case of frame conflict in our language about language”, in Ortony, A. (Ed), Metaphor and thought, Cambridge University Press, Cambridge:

Rindfleisch, A. and Moorman, C. (2001), "The acquisition and utilization of information in new product alliances: a strength-of-ties perspective”, Journal of Marketing, Vol 65 No 2, pp. 1-18.

Shotter, J. (1993), Conversational Realities: Constructing Life through Language, Sage Publications, London.

Steensma, H. K. and Corley, K. G. (2000), "On the performance of technology-sourcing partnerships: the interaction between partner interdependence and technology attributes", Academy of Management Journal, Vol 43 No 6, pp. 1045-1067.

Stein, E. W. and Zwass, V. (1995), “Actualizing organizational memory with information systems”, Information Systems Research, Vol 6 No 2, pp. 85-117. 
Szulanski, G. (2000), "The process of knowledge transfer: a diachronic analysis of stickiness”, Organizational behavior and human decision processes, Vol 82 No 1, pp. 9-27.

Teece, D. J. (2001), "Strategies for managing knowledge assets: the role of firm structure and industrial context”, In Nonaka, I. and Teece, D.J. (Eds.), Managing Industrial Knowledge: Creation, Transfer and Utilzation, Sage Publications: London, pp. 125-144.

Tulving, E. (1983), Elements of episodic memory, Oxford University Press, Oxford.

Wah, L. (1999), “Behind the buzz”, Management Review, Vol 88 No 4, pp.17-26.

Walker, G., Kogut, B. and Shan, W. (1997), "Social capital, structural holes, and the formation of an industry network”, Organizational Science, Vol 8 No 2, pp. 109-125.

Walther, J. B. (1995), "Relational aspects of computer-mediated communication: experimental observations over time”, Organization Science, Vol 6 No 2, pp. 186-203.

Walsh, J. P. and Ungson, G. R. (1991), “Organizational Memory”, Academy of Management Review, Vol 16 No 1, pp. 57-91.

Wenger, E. (1998), Communities of practice: learning, meaning, and identity, Cambridge University Press: Cambridge.

Wenger, E., McDermott, R. and Snyder, W. M. (2002), Cultivating communities of practice: a guide to managing knowledge, Harvard Business School Press: Boston, Mass.

Woolcock, M. (1998), "Social capital and economic development: towards a theoretical synthesis and policy framework”, Theory and Society, Vol 27 No 2, pp. 151-208.

Wright, M. and Edwards, P. (2001), "Modes of integration and the diffusion of best practices in the multinational enterprise”, In Taggart, J. H., Berry, M. and McDermott, M. (Eds.), Multinational in a New Era: International Strategy and Management, Palgrave: Houndsmill, Basingstoke, pp. 141-152. 
Figure 1: Knowledge Retrieval Means

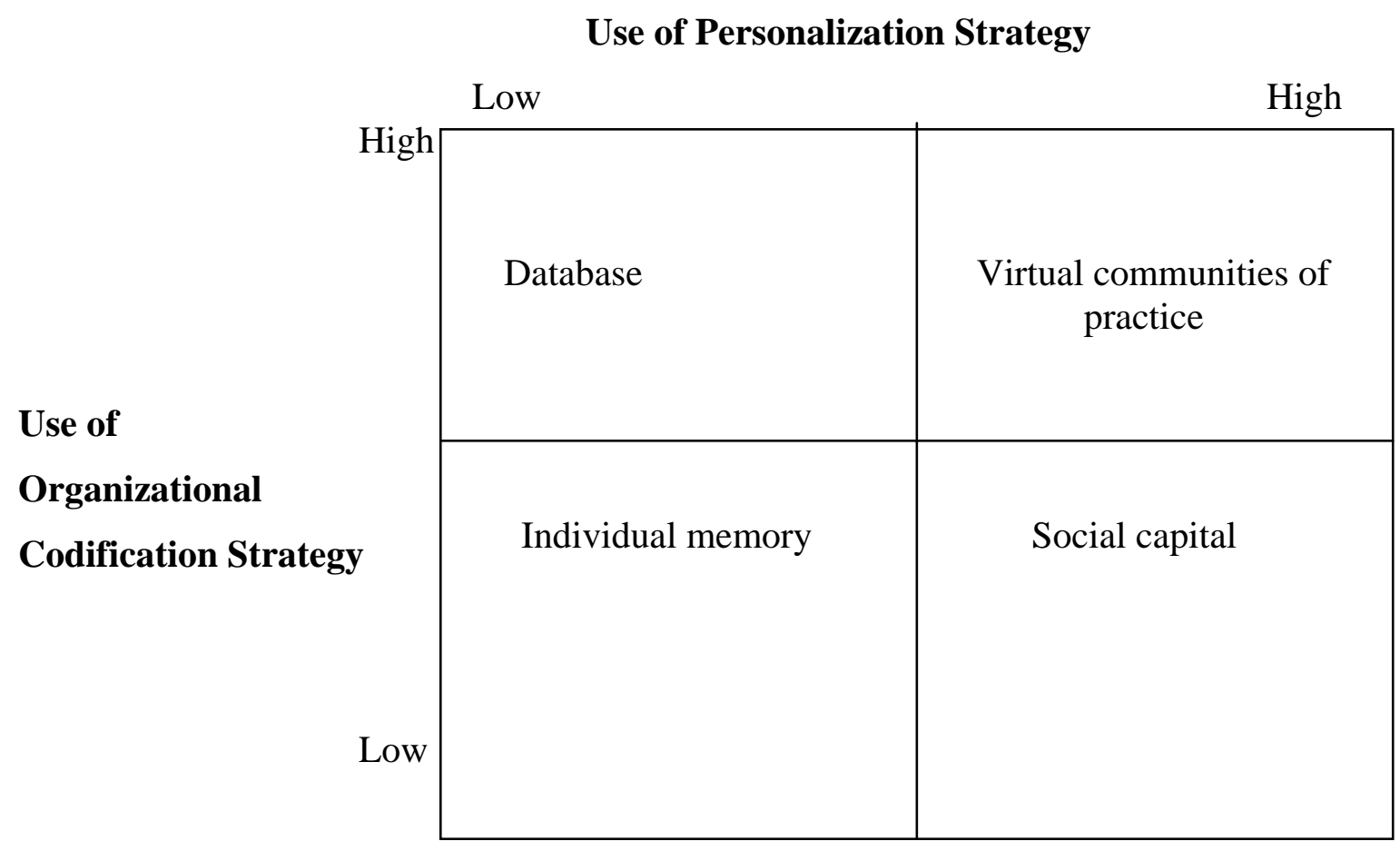

